\title{
Biopsy of Colon
}

National Cancer Institute

\section{Source}

National Cancer Institute. Biopsy of Colon. NCI Thesaurus. Code C51678.

Removal of tissue from the colon for microscopic examination, using an endoscope. 